\title{
THE STRATEGIES OF TARGETING CONSUMER BUYING DECISION IN PALMART MINIMARKET, PONTIANAK
}

\author{
Zul Fahmi \\ Faculty of Economics Panca Bhakti University \\ zulfahmi2011@gmail.com \\ Dina Octaviani \\ Faculty of Economics Panca Bhakti University \\ dinaoctaviani84@yahoo.co.id
}

\begin{abstract}
Retail business that is now very popular is a business that supports many people and gives many benefits to some people. Minimarket, which has long been known to the people of Pontianak, is a form of retail business that is very rapidly growing and its existence is very beneficial to the community. For that, producers need strategies with the objective of achieving competitive advantage and need information about factors that influence consumer behavior in making decisions regarding the purchase of products. The purpose of this study is to find out how the strategy of targeting consumer buying decisions in Palmart Minimarket, Pontianak. This type of research is survey research and data collection techniques used was questionnaire, while the respondents were consumers who had shopped in Palmart Minimarket Pontianak, the data analysis technique used was the Factor Analysis method with Accurate Use correlation/correlation matrix between variables using Bartlett Test of Sphericity or Measure of Sampling Adequacy (MSA). The value of KMO/MSA ranges from 0 - 1 with the criteria used for interpretation. The expected target in this study was to inform how the right strategy of Targeting Consumer Buying Decisions in the Palmart Minimarket, Pontianak. The output of this research is teaching material, paper for national scientific seminars, and publications in national-accredited scientific journals.
\end{abstract}

Keywords: consumer shopping behavior, price, quality, distribution, promotion, factor analysis, buying decision.

\begin{abstract}
Bisnis ritel yang kini sangat populer adalah bisnis yang mendukung banyak orang dan memberi banyak manfaat bagi sebagian orang. Minimarket, yang sudah lama dikenal masyarakat Pontianak, adalah bentuk bisnis ritel yang berkembang sangat pesat dan keberadaannya sangat bermanfaat bagi masyarakat. Untuk itu, produsen membutuhkan strategi dengan tujuan mencapai keunggulan kompetitif dan membutuhkan informasi tentang faktor-faktor yang memengaruhi perilaku konsumen dalam mengambil keputusan terkait pembelian produk. Tujuan dari penelitian ini adalah untuk mengetahui bagaimana strategi penargetan keputusan pembelian konsumen di Palmart Minimarket, Pontianak. Jenis penelitian ini adalah penelitian survei dan teknik pengumpulan data yang digunakan adalah kuesioner, sedangkan respondennya adalah konsumen yang pernah berbelanja di Palmart Minimarket Pontianak, teknik analisis data yang digunakan adalah metode Analisis Faktor dengan menggunakan matriks korelasi / korelasi Korelasi Akurat / korelasi antara variabelvariabel menggunakan Uji Bartlett Sphericity atau Measure of Sampling Adequacy (MSA). Nilai KMO / MSA berkisar dari 0 - 1 dengan kriteria yang digunakan untuk interpretasi. Target yang diharapkan dalam penelitian ini adalah untuk menginformasikan bagaimana
\end{abstract}


strategi yang tepat dalam Menargetkan Keputusan Pembelian Konsumen di Palmart Minimarket, Pontianak. Keluaran dari penelitian ini adalah bahan ajar, makalah untuk seminar ilmiah nasional, dan publikasi di jurnal ilmiah terakreditasi nasional.

Kata Kunci: prilaku belanja konsumen, harga, kualitas, distribusi, promosi, analisis faktor, keputusan pembelian.

\section{JEL: M31}

\section{Research Background}

The form of retail or retail business (retailing) can be understood as all activities involved in the sale of goods or services directly to end consumers for personal use and not business use (Sekaran 2006:4), The development of retail business from year to year is increasing as evidenced by so many emerging retail trade in the form of shops, minimarkets, department stores, supermarkets, and others.

In accordance with the one written by Suliyanto (2005: 28), the following shows that the development of the retail market in Indonesia continues to increase. Rapid growth in retail companies will lead to high competition. The main key for companies to remain competitive is that companies must be able to take advantage of existing business opportunities and try to implement the right marketing strategies in order to dominate the market.

Understanding the market is an important activity for the company in maintaining the viability of its business, growing, and obtaining optimal profits. This is in line with what was stated by Porter (2000: 15) that the main goal of each company that carries out a marketing strategy is that the company can remain in the market and at the same time be able to control the market amid increasing competition.

In dealing with competition, retailers must develop retail marketing strategies based on the overall goals (objectives) and strategic plans that match with the nature and type of the market it faces. Retail objectives can be in the form of an increasing number of visitors or consumers, higher product sales, or perhaps a rising store image.

While in general, the strategic plan or key (main) tasks in retail are selecting and setting target markets and developing "Six P" of the retail mix in order to successfully meet the needs of the selected target markets. "Six P" consists of traditional "Four P" (product, price, place, promotion) plus personnel and presentation.

Retailers combine the elements of the retail mix to create a single retail method to attract target markets. This combination of "Six P" projects the image of a store that will affect consumers' perceptions (Silverman 2001: 95-97)

Understanding consumer behavior is not something that is easy, but quite difficult and complex, especially due to the number of variables that influence and are interrelated in describing how consumers make buying decisions including analysis of factors that influence product purchase and use decisions. In general, the consumer spending process will follow various stages including introduction to needs, information seeking, evaluation of various alternatives, determining choices, shopping transactions, and shopping evaluation (Sekaran, 2006: 37).

Buying decisions usually require considerations that really support and can satisfy buyers. The consumer decision-making process cannot happen by itself, on the contrary, there are many factors that influence it. Cultural, social, individual, and psychological problems strongly influence consumer decisions. Those factors influence consumers from the time consumers receive stimuli to post-purchase behavior (Silverman 2001: 201). Consumer behavior is finally seen when consumers make buying decisions, not only on the choice of products and brands, consumers also choose which outlets they visit, when they shop, and how 
much they spend. This occurs in the buying decision process and according to their own characteristics in receiving an external stimulus (Suliyanto 2005: 63)

From observations in the field, it appears that Palmart Minimarket looks more crowded with consumers to shop than its closest competitors. The total number of consumers of the Palmart Minimarket every month or year, but based on observations and also information from the minimarket, the daily average number of consumers in the minimarket reaches more than 300 people and the sales revenue data of Palmart minimarket can be seen in table 1 below:

Table 1. Palmart Minimarket Consumer Purchase Intensity in 2014-2016

\begin{tabular}{ccc}
\hline No & Year & Consumer Purchase Intensity \\
\hline 1 & 2014 & Rp. 13,638,833,100 \\
2 & 2015 & Rp. 15,033,813,600 \\
3 & 2016 & Rp. 15,529,237,500 \\
\hline
\end{tabular}

Source: Palmart Minimarket

Based on the average consumer and the Consumer Purchase Intensity data table in Palmart Minimarket above, it can be seen that the amount of sales revenue has increased. Observations along with information from the minimarket during the observation, even though every day it seems crowded to be visited by buyers, Palmart Minimarket does not implement a specific strategy in its retail mix. In terms of price and service levels, the minimarket provides a standard service that not much different from other supermarkets. In fact, the researchers considered that the level of Palmart customer service (service to customers) is still behind compared to other supermarkets, for example, cashiers and salespeople are still less communicative to customers when compared to other supermarkets.

Based on the description above, it can be seen that the Palmart Minimarket has the potential and is able to compete with other minimarkets. Table 1 shows an increase in the consumer purchase intensity which can be further improved by using the right marketing strategy. This study aims to find out the right strategy of Targeting Consumer Buying Decisions in the Palmart Minimarket, Pontianak. Marketing strategy to determine factors product, price, location, and service that have the most influence on consumer decisions to shop at Palmart Minimarket.

The results of this study can be useful for Palmart Minimarket in particular and similar minimarkets around it in general. The right marketing strategy will have an impact on increasing consumer spending and lead to an increase in the company's turnover.

Rapid growth in retail companies will lead to high competition among these companies. In order to remain competitive, companies must be able to take advantage of existing business opportunities and try to implement the right marketing strategies in order to dominate the market. Understanding the market is an important activity for the company in maintaining the viability of its business and growing while obtaining optimal profits.

In dealing with competition, retailers must develop retail marketing strategies based on the overall goals (objectives) and strategic plans that match with the nature and type of the market it faces. Broadly speaking, the strategic plan or key (main) tasks in retail are selecting and setting target markets and developing "Six P" of the retail mix in order to successfully meet the needs of the selected target markets. This combination of Six P projects the image of a store that will affect consumers' perceptions.

The consumer decision-making process cannot happen on its own, but on the contrary, many factors contribute to it. Consumers have an influence from the time consumers receive stimuli to post-purchase behavior. Consumer behavior is ultimately seen when consumers make buying decisions. Not only the choice of products and brands, consumers also choose which outlets they visit, when they shop, and how much they spend. This occurs in the buying 
decision process and according to their own characteristics in receiving an external stimulus. This shopping decision can be described in the fishbone framework as follows:

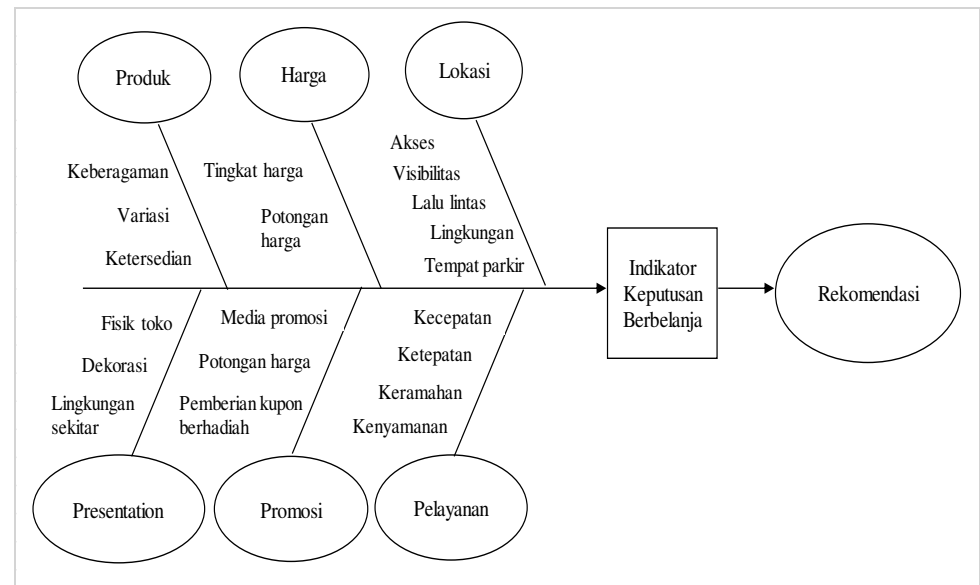

Figure 1 Fishbone Framework

\section{Research Method}

The type of research used in this study was descriptive analysis. According to Husein Umar in Komsatun (2005: 27), descriptive analysis is a study that aims to describe the nature or characteristics of a particular phenomenon. The consideration in using the descriptive method was to know the overall consumer perceptions of products, prices, locations, and services that influence their shopping decisions at Palmart Minimarket Pontianak.

Data collection techniques applied 3 methods as follows: First, observation Technique. Observation is "how to collect data by going and looking directly into the field, towards the object under study" Hasan (2002: 17). In this observation technique, the researchers visited the service unit at the Office of Indosat in Pontianak. Second is interview technique. An Interview is "how to collect data directly by carrying out a question and answer to the object under study or to an intermediary who knows the problem of the object under study" Hasan (2002: 17). With interview techniques, the researchers can directly ask the objects. The last is questionnaire technique. A Questionnaire is "how to collect data using a list of questions (questionnaire) or a checklist of the object under study (population)" Hasan (2002: 17). This technique is carried out by giving or distributing questionnaires to selected respondents.

A population is the whole individuals, objects, symptoms, or events studied (Hadi in Solomon 2009: 39). In this study, the population was all buyers or consumers at Palmart Minimarket. The number of Palmart Minimarket consumers is unlimited, so the population is unlimited. In this study, not all consumers of the Minimarket were taken as the object of research (respondents), but only a portion of the population who were considered able to represent the population as respondents. The sampling technique used in this study was accidental sampling, which is anyone who happened to be met shopping at the Minimarket during the study.

In this study, the determination of the number of samples from unknown populations was sought using the Malhotra formula, which is a minimum of 4 or 5 multiplied by the number of sub-variables (Santosa dan Ashari 2004: 105). From the Malhotra formula, calculations can be made to find the number of samples as follows:

$$
\begin{aligned}
\mathrm{n} & =4 \times \text { number of sub-variables } \\
& =4 \times 20=80
\end{aligned}
$$

Thus, the number of samples taken in this study is 80 respondents. 
The data analysis method used factor analysis, validity, and reliability tests. The results of the calculation of factor analysis based on KMO/MSA values show that the value of $\mathrm{KMO} / \mathrm{MSA}$ is $0.515>0.5$ and the level of sig is $0.001<0.05$, so the data is considered valid. The provisions of a valid variable are based on the following criteria and hypotheses:

1. If the probability ( $\mathrm{sig}$ ) $<0.05$ then the variable can be analyzed further;

2 . If the probability (sig) $>0.05$ then the variable cannot be analyzed further.

\section{Result and Discussion}

Respondent characteristics refer to the characteristics of the respondents in the study. The number of respondents in this study were 80 people who happened to be met shopping at Palmart Minimarket during the study.

From the results of the questionnaire, information about the characteristics of 80 respondents who were the samples in this study was obtained. The characteristics of the respondents were as follows:

Table 3. Characteristics of Respondents

\begin{tabular}{|c|c|c|}
\hline Characteristics of Respondents & Quantity (people) & Percentage $(\%)$ \\
\hline \multicolumn{3}{|l|}{ Age level } \\
\hline$<19$ years & 22 & 27.5 \\
\hline 20 - 30 years & 25 & 31.25 \\
\hline $31-40$ years & 19 & 23.75 \\
\hline $41-59$ years & 11 & 13.75 \\
\hline$>60$ years & 3 & 3.75 \\
\hline Total & 80 & 100 \\
\hline \multicolumn{3}{|l|}{ Gender } \\
\hline Male & 31 & 38.75 \\
\hline Female & 49 & 61.25 \\
\hline Total & 80 & 100 \\
\hline \multicolumn{3}{|l|}{ Education level } \\
\hline Elementary School & 5 & 6.25 \\
\hline Junior High School or equivalent & 11 & 13.75 \\
\hline Senior High School or equivalent & 35 & 43.75 \\
\hline Diploma & 18 & 22.5 \\
\hline Bachelor (S1) & 11 & 13.75 \\
\hline Total & 80 & 100 \\
\hline \multicolumn{3}{|l|}{ Occupation } \\
\hline Student/university student & 26 & 32.5 \\
\hline Private employee & 13 & 16.25 \\
\hline Civil Servant & 8 & 10 \\
\hline Businessman /Private & 19 & 23.75 \\
\hline Others & 14 & 17.5 \\
\hline Total & 80 & 100 \\
\hline \multicolumn{3}{|l|}{ Income level } \\
\hline$<\operatorname{Rp} 1,000,000$ & 25 & 31.25 \\
\hline Rp 1,000,000 - Rp 2,000,000 & 20 & 25 \\
\hline Rp 2,100,000 - Rp 3,000,000 & 16 & 20 \\
\hline Rp 3,100,000 - Rp 5,000,000 & 15 & 18.75 \\
\hline$>\operatorname{Rp} 5,000,000$ & 4 & 5 \\
\hline Total & 80 & 100 \\
\hline
\end{tabular}

Source: Processed data, 2018 
In factor analysis, the validity and reliability testing were measured based on KMO / MSA values with the following table

Table 4. KMO and Bartlett's Test

\begin{tabular}{cll}
\hline Kaiser-Meyer-Olkin Measure of Sampling Adequacy. .515 \\
\hline \multirow{3}{*}{ Bartlett's Test of Sphericity } & Approx. Chi-Square & 37.399 \\
& Df & 15 \\
& Sig. & .001 \\
\hline Source: Processed data, 2018 &
\end{tabular}

Based on the KMO and Bartlett's Test Table 4, it can be seen that the value of $\mathrm{KMO} / \mathrm{MSA}$ is $0.515>0.5$ and the level of sig is $0.001<0.05$, so that the data is considered valid. The number of $\mathrm{KMO} / \mathrm{MSA}$ ranges from $0-1$ with the criteria used for interpretation as follows:

1. If MSA $=1$ then the variable can be predicted without errors by other variables;

2. If $\mathrm{MSA}=>0.5$ then the variable can still be predicted and can be analyzed further;

3. If MSA $<0.5$ then the variable cannot be predicted and cannot be analyzed further so that the variable must be removed or discarded.

Factor analysis was used to identify variables that are not directly observed or factors (also called latent variables) that explain the pattern of relationships in a set of variables. The use of this factor analysis aims to analyze a number of variables which are basically based on theory, actual reality, and analyze the relationship between variables to determine what variations appear in these variables based on a number of basic factors which are fewer than the number of variables. In other words, the main purpose of this analysis is to summarize the information contained in a large number of variables into a smaller group of factors.

Based on the KMO and Bartlett's Test Table 5, it was obtained the KMO Measure of sampling Adequacy value 0.515 with a sig level of 0.001 . Because the value of MSA>0.5 and sig $<0.05$, the variables and data above can be further analyzed. These provisions were based on the following criteria and hypotheses:

1. If the probability (sig) $<0.05$ then the variable can be analyzed further;

2 . If the probability (sig) $>0.05$ then the variable cannot be analyzed further.

Whereas, the number of KMO/MSA ranges from 0-1 with the criteria used for Interpretation as follows:

1. If $\mathrm{MSA}=1$ then the variable can be predicted without errors by other variables;

2. If $\mathrm{MSA}=>0.5$ then the variable can still be predicted and can be analyzed further;

3. If MSA $<0.5$ then the variable is not predictable and cannot be analyzed further so that the variable must be removed or discarded.

Then for the anti-image table, if there is an anti-image correlation value that is shown in a diagonal line with a symbol whose value $<0.5$, it means that the attribute is issued and retested.

The results of the initial analysis showing the number of MSA in the anti-image matrix table contained in the anti-image correlation show the values for the variables studied were as follows:

1. Product $=0.460$

2. Price $=0.312$

3. Location $\quad=0.514$

4. Service $=0.553$

5. Promotion $=0.599$

6. Presentation $=0.575$ 
Table 5. Results of Initial Phase Factor Analysis Calculation

KMO and Bartlett's Test

Kaiser-Meyer-Olkin Measure of Sampling Adequacy.

.515

Approx. Chi-Square

37.399

Bartlett's Test of Df

Sphericity

Sig.

.001

Anti-image Matrices

\begin{tabular}{|c|c|c|c|c|c|c|c|}
\hline & \multicolumn{3}{|c|}{ Anti-image Matrices } & \multirow[b]{2}{*}{ Service } & \multirow[b]{2}{*}{ Promotion } & \multirow[b]{2}{*}{ Presentation } \\
\hline & & Product & Price & Location & & & \\
\hline Anti-image & Product & .839 & .160 & .249 & .166 & -.071 & .063 \\
\hline Covariance & Price & .160 & .939 & .128 & .064 & -.099 & .115 \\
\hline & Location & .249 & .128 & .702 & -.024 & -.208 & .269 \\
\hline & Service & .166 & .064 & -.024 & .952 & .044 & .017 \\
\hline & Promotion & -.071 & -.099 & -.208 & .044 & .877 & .087 \\
\hline & Presentation & .063 & .115 & .269 & .017 & .087 & .821 \\
\hline Anti-image & Product & $.460^{\mathrm{a}}$ & .180 & .325 & .185 & -.083 & .076 \\
\hline Correlation & Price & .180 & $.312^{\mathrm{a}}$ & .158 & .068 & -.109 & .131 \\
\hline & Location & .325 & .158 & $.514^{\mathrm{a}}$ & -.029 & -.265 & .355 \\
\hline & Service & .185 & .068 & -.029 & $.553^{\mathrm{a}}$ & .049 & .019 \\
\hline & Promotion & -.083 & -.109 & -.265 & .049 & $.599^{\mathrm{a}}$ & .102 \\
\hline & Presentation & .076 & .131 & .355 & .019 & .102 & $.575^{\mathrm{a}}$ \\
\hline
\end{tabular}

a. Measures of Sampling

Adequacy(MSA)

If seen in the anti-image table above, the variables of Location, Service, Promotion, and Presentation had MSA>0.5. So that further analysis was carried out with the following results:

Table 6. Results of Calculation of Final Phase Factor Analysis Calculation KMO and Bartlett's Test

\begin{tabular}{|c|c|c|c|c|c|}
\hline \multicolumn{4}{|c|}{ Kaiser-Meyer-Olkin Measure of Sampling Adequacy. } & \multicolumn{2}{|l|}{594} \\
\hline \multirow{3}{*}{ Bartlett's Test of Sphericity } & \multicolumn{2}{|c|}{ Approx. Chi-Square } & & \multicolumn{2}{|c|}{21.931} \\
\hline & \multicolumn{2}{|c|}{ Df } & & \multicolumn{2}{|c|}{6} \\
\hline & \multicolumn{2}{|l|}{ Sig. } & & \multicolumn{2}{|c|}{.001} \\
\hline \multicolumn{6}{|c|}{ Anti-image Matrices } \\
\hline & & Location & Service & Prom & Presentation \\
\hline \multirow[t]{4}{*}{ Anti-image Covariance } & Location & .794 & -.089 & -.205 & .278 \\
\hline & Service & -.089 & .987 & .065 & .001 \\
\hline & Promotion & -.205 & .065 & .891 & .106 \\
\hline & Presentation & .278 & .001 & .106 & .838 \\
\hline \multirow[t]{4}{*}{ Anti-image Correlation } & Location & $.572^{\mathrm{a}}$ & -.101 & -.244 & .341 \\
\hline & Service & -.101 & $.415^{\mathrm{a}}$ & .069 & .001 \\
\hline & Promotion & -.244 & .069 & $.643^{\mathrm{a}}$ & .122 \\
\hline & Presentation & .341 & .001 & .122 & $.604^{\mathrm{a}}$ \\
\hline
\end{tabular}

a. Measures of Sampling Adequacy(MSA) 
Based on the Table 6, the results of the final analysis showed the number of MSA in the anti-matrix image table contained in the anti-image correlation indicating the location value was 0.572 , Service was 0.415 , Promotion was 0.643 , and Presentation was 0.604 .

In this case, the KMO/MSA value of the service variable was $0.415<0.5$, meaning that this variable is not included in the factors that influence consumer buying decisions. Thereby, it can be seen that the variables that influence consumers buying decisions are location, promotion, and presentation.

\section{Conclusion}

Based on the data collected in the field (80 respondents), the characteristics of respondents by age level were more dominated by the age of 20 to 30 years as many as 25 respondents or $31.25 \%$; by sex, more female than male with 49 respondents or $61.25 \%$; by education level, more high school/equivalent with 35 respondents or $43.75 \%$; by occupation, dominated by 26 students/university students amounting to $32.5 \%$; and by level of income, dominated by 25 respondents with $<$ Rp. $1,000,000$ or equal to $31.25 \%$.

Analysis of consumer buying decision factors at the Palmart Minimarket Pontianak shows the initial analysis of MSA numbers in the anti-matrix image table contained in the antiimage correlation showing the value for Product variable was 0.460, Price was 0.312, Location was 0.514 , Service was 0.553 , Promotion was 0.599 , and Presentation was 0.575 . In the initial analysis, the variables of Location, Service, Promotion, and Presentation which had MSA>0.5 were then analyzed further. The final analysis results showed the number of MSA in the antimatrix image table contained in the anti-image correlation showing the value of Location was 0.572 , Service was 0.415 , Promotion was 0.643 , and Presentation was 0.604 .

The KMO/MSA value of the service variable was $0.415<0.5$, meaning that this variable is not included in the factors that influence consumer buying decisions. Therefore, it can be seen that the variables that influence consumer buying decisions are location, promotion, and presentation.

Based on the results of the data analysis, several constructive suggestions are given to the management of Palmart Minimarket Pontianak as follows:

Factors that influence consumers buying decisions at the Palmart Minimarket are location, promotion, and presentation (shop appearance), therefore it is expected that the management can increase its existence by increasing security in parking lots, adding CCTV, promoting not only through advertising but also spreading brochures and in terms of store appearance, Palmart can add a new exterior such as music, thus making consumers more comfortable in shopping.

Even though the variables of product, price, and service are not the factors that affect consumers buying decisions, management must still focus on these three variables. Management must maintain product levels, prices, and services, for example, by maintaining product price levels so as not to exceed market prices and increase service in terms of speed and accuracy, because there were respondents who strongly disagree with the speed of service provided. In addition, the management can add more cashier counters so as not to cause the queue to be too long. Likewise, the management can analyze to find out more about why the product, price, and service variables are not included in the factors that influence consumer buying decisions in Palmart Minimarket to be used as a benchmark for previous achievements. 


\section{References}

Hasan, A. 2010. Marketing dari mulut ke mulut. Yogyakarta: Media Presindo.

Porter K. 2008. Marketing Management $12^{\text {th }}$ ed. Jakarta: Indeks.

Solomon M. 2009. Consumer behavior buying, having, and being (8th ed.). New York: Prentice Hall.

Santosa PB, Ashari. 2005. Analisis statistik dengan Microsoft Excel dan SPSS. Yogyakarta: ANDI.

Sekaran U. 2006. Metodologi penelitian untuk bisnis (4th ed.). Jakarta: Salemba Empat.

Silverman G. 2001. The secret of word of mouth marketing: How to trigger exponential sales through runaway word of mouth. United States of America: Amacam.

Suliyanto. 2005. Analisis data dalam aplikasi pemasaran. Bogor: Ghalia Indonesia. 